\begin{tabular}{|c|c|}
\hline 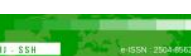 & Malaysian Journal of Social Sciences and Humanities (MJSSH) \\
\hline Malaysian Journal of & Volume 6, Issue 1, January 2021 \\
\hline (MJ-SSH) & e-ISSN : 2504-8562 \\
\hline & $\begin{array}{l}\text { Journal home page: } \\
\text { www.msocialsciences.com }\end{array}$ \\
\hline
\end{tabular}

\title{
Wacana Kontroversi Agama di Malaysia: Satu Kajian Terhadap Pelaporan Akhbar Utusan Malaysia dan The Star Mengenai Tuntutan COMANGO
}

Muhammad Raqib Mohd Sofian'1, Azman Azwan Azmawati ${ }^{1}$

${ }^{1}$ Pusat Pengajian Komunikasi, Universiti Sains Malaysia (USM)

Correspondence: Muhammad Raqib Mohd Sofian (raqibsofian@gmail.com)

\begin{abstract}
Abstrak
Negara Malaysia sebelum ini telah mengalami pelbagai insiden dan isu yang melibatkan kaum dan agama sehingga telah mendatangkan masalah dari segi perhubungan antara kaum dan agama. Isu-isu yang melibatkan agama dan kaum ini sering kali melibatkan agama Islam, yang juga adalah agama rasmi negara Malaysia. Agama Islam sering kali menjadi subjek yang sensitif kerana ia sering kali dijadikan sebagai alat untuk mengekalkan hegemoni dan status quo oleh pihak kerajaan dalam konteks di Malaysia. Pada tahun 2013, sebuah pertubuhan NGO yang dikenali sebagai COMANGO telah menghantar beberapa tuntutan yang melibatkan hak asasi manusia di Malaysia kepada Pertubuhan Bangsa-bangsa Bersatu (PBB) di Penilaian Berkala Sejagat (UPR). COMANGO telah dikatakan telah membuat beberapa tuntutan yang mencabar kedudukan Islam dan Melayu di Malaysia dan mempromosi seks bebas. Isu ini telah mendapat liputan yang meluas di media akhbar di Malaysia khususnya akhbar arus perdana di Malaysia dan ia dilihat sebagai sebuah isu yang boleh mendatangkan manfaat kepada pihak kerajaan untuk mengukuhkan kuasa mereka dengan memainkan isu ini kepada khalayak umum. Oleh itu, artikel ini bertujuan untuk mengkaji mesej-mesej yang disampaikan oleh akhbar arus perdana mengenai isu ini, iaitu akhbar Utusan Malaysia dan The Star. Dapatan kajian menunjukkan kedua-dua akhbar yang dikaji memberikan liputan yang hampir sama dengan sedikit kelainan. Akhbar Utusan Malaysia dilihat sangat menentang tuntutan COMANGO tersebut dan mengangkat parti UMNO sebagai parti yang memperjuangkan Islam manakala akhbar The Star walaupun dilihat lebih banyak memberikan peluang kepada pihak COMANGO untuk menyatakan pendirian mereka, namun dilihat masih berhatihati dalam pelaporan mereka mengenai isu tersebut.
\end{abstract}

Kata kunci: hegemoni, pemaparan media, akhbar Malaysia, Islam, COMANGO

\section{Discourse on Religious Controversy in Malaysia: A Study on the Report of Utusan Malaysia and The Star on COMANGO Demands}

\begin{abstract}
Malaysia has previously experienced various incidents and issues involving race and religion and it has caused problems in terms of relations between races and religions. Issues involving religion and race often involve Islam, which is also the official religion of Malaysia. Islam is often a sensitive subject because it is often used as a tool to maintain the hegemony and status quo by the government in the context of Malaysia. In 2013, a non-governmental organization known as " COMANGO" submitted several demands involving human rights in Malaysia to the United Nations (UN) at the Universal Periodic Assessment (UPR). COMANGO was said to have made several demands that challenged the
\end{abstract}


position of Islam and Malays in Malaysia and also promoting free sex. This issue has received widespread coverage in the Malaysian press; especially the mainstream press and it is seen as an issue that can benefit the government to strengthen their power by playing this issue to the general public. Therefore, this article aims to examine the messages delivered by the mainstream press on this issue, specifically Utusan Malaysia and The Star. The findings of the study show that the two newspapers provide almost the same coverage with little differences. Utusan Malaysia is seen as strongly opposing to COMANGO demands and elevates the UMNO party as a party that really fight for Islam while The Star, although seen as giving COMANGO more opportunities to express their stance, is seen to be cautious in their reporting on the issue.

Keywords: hegemony, media portrayal, Malaysian press, Islam, COMANGO

\section{Pengenalan}

Isu-isu konflik melibatkan kaum dan agama sering kali dibincangkan di media massa di Malaysia lebihlebih lagi selepas tsunami politik yang berlaku pada tahun 2008 yang mana Barisan Nasional telah kehilangan majoriti $2 / 3$ parlimen dalam arena politik negara. Kebanyakan isu konflik ini sering kali melibatkan agama Islam yang juga agama rasmi negara Malaysia, malah majoriti penduduk di Malaysia adalah Melayu Islam (Yang \& Md Sidin, 2011; Carmen, 2012; Muhammad Raqib \& Adnan Hussein, 2014; Eichenauer, 2016; Muhammad Raqib \& Adnan, 2018). Islam sering kali dijadikan subjek perbincangan dalam isu-isu konflik ini kerana ia sering kali dijadikan sebagai alat politik oleh sesetengah pihak yang berkepentingan untuk mengekalkan kuasa hegemoni dan status quo yang sedia ada (Wan Norshira, 2019). Malah media akhbar khususnya turut digunakan sebagai alat oleh golongan berkuasa untuk menyampaikan idea-idea golongan dominan ini kepada masyarakat (ibid).

Secara amnya, $60 \%$ populasi rakyat Malaysia adalah dari golongan Melayu Islam, manakala selebihnya terdiri daripada kaum dan entik lain termasuk Cina, India dan masyarakat Bumiputera di Sabah dan Sarawak (Mohd Farid, 2012, Ridauddin Daud, 2020). Dari segi Perlembagaan Malaysia pula, terdapat beberapa peruntukan yang termaktub dalam Perlembagaan yang memberikan kelebihan kepada golongan Melayu Islam dan kaum Bumiputera seperti Islam adalah agama rasmi negara dan bahasa Malaysia adalah bahasa kebangsaan negara Malaysia (Abdul Aziz, 2001). Malah terdapat beberapa peruntukan lain yang turut memberikan kelebihan kepada golongan Melayu Islam dan Bumiputera yang lain dalam beberapa bidang seperti pendidikan dan ekonomi (ibid). Namun, hak-hak golongan bukan Melayu juga turut terjaga dan terjamin dalam Perlembagaan negara (ibid).

Perkara ini menyebabkan golongan bukan Melayu di Malaysia merasakan diri mereka ditindas dengan polisi-polisi yang diperkenalkan oleh pihak kerajaan yang diterajui oleh UMNO (parti Melayu Islam paling dominan di Malaysia sebelum Pilihan Raya Umum 2018) yang melebihkan golongan Melayu Islam dan Bumiputera (Neo, 2006; Walters, 2007; Jha ,2009). Parti UMNO turut sering kali digambarkan sebagai satu-satunya parti yang memperjuangkan Islam, Melayu dan memperjuangkan kemerdekaan Malaya pada tahun 1957 (Yang \& Md Sidin, 2011; Yang \& Md Sidin, 2012). Parti UMNO juga sebelum ini sering kali menggunakan faktor agama dan bangsa dalam menakut-nakutkan golongan Melayu Islam mengenai masa hadapan mereka di tanah Melayu dalam usaha mereka untuk mengekalkan status quo dan mendapatkan sokongan berterusan golongan Melayu Islam (Wan Norshira, 2019). Malah, media akhbar turut digunakan sebagai alat untuk membina ideologi ini secara tersirat dalam minda rakyat Malaysia terutamanya golongan Melayu Islam (ibid).

Pada tahun 2013, terdapat beberapa pihak dalam kalangan Melayu Islam di Malaysia terutamanya pertubuhan bukan kerajaan (NGO) Melayu Islam yang rapat dengan parti UMNO telah menyuarakan ketidak puasan hati mereka mengenai pertubuhan COMANGO yang dikatakan telah mencabar kesucian Islam dan menggugat status agama Islam sebagai agama rasmi Malaysia (Comango: Our UN report does not undermine Islam, 2013). COMANGO atau dikenal sebagai "Coalition of Malaysian NGO's in the UPR Process" ditubuhkan pada tahun 2008 bersama dengan 54 buah organisasi, antaranya EMPOWER 
(Persatuan Kesedaran Komuniti Selangor), SUARAM (Suara Rakyat Malaysia), All Women's Action Society (AWAM), Centre for Independent Journalism (CIJ), Voice of the Children (VOC), Yayasan Chow Kit dan Persatuan Guru-Guru Tadika (Abdul Qayyum Jumadi, 2014; Earnie dan rakan-rakan, 2019). COMANGO dikatakan telah menghantar beberapa tuntutan yang melibatkan hak asasi manusia di Malaysia kepada Pertubuhan Bangsa-bangsa Bersatu (PBB) di Penilaian Berkala Sejagat (UPR) yang telah diadakan di Geneva, Switzerland (ibid). COMANGO juga telah dikatakan telah membuat beberapa tuntutan yang mempromosikan dan memperjuangkan seks bebas dan kebebasan beragama yang jelas bercanggah dengan ajaran Islam yang diamalkan di Malaysia (Abdul Qayuum, 2014).

Kesan dari tuntutan COMANGO ini, pelbagai tindakan telah diambil oleh NGO Melayu Islam dan salah satunya adalah terdapatnya satu kempen telah dilancarkan oleh Ikatan Muslimin Malaya (ISMA) yang dikenali sebagai 'Sejuta Ummah Tolak COMANGO (Abdul Qayyum, 2014). Beberapa NGO Melayu Islam turut mengadakan pelbagai seminar untuk menerangkan kepada masyarakat Islam mengenai bahaya tuntutan COMANGO ini, antaranya adalah "Forum COMANGO: Islam tercabar di Geneva-di mana suara ummah?” yang diadakan pada 16 November 2013 (Earnie \& rakan-rakan, 2019).

Namun begitu, pihak COMANGO telah menafikan bahawa pertubuhan tersebut bertujuan untuk menjatuhkan Islam di Malaysia seperti didakwa namun ia lebih untuk memperjuangkan kondisi hak asasi manusia di Malaysia (COMANGO: We are not for rights against Islam, 2014). COMANGO dikatakan hanya menyokong kebebasan beragama serta hak individu untuk bebas dari keganasan tidak kira wanita, kanak-kanak, orang tua, orang kurang upaya tanpa mengira orientasi seksual dan identiti jantina (Earnie dan rakan-rakan, 2019). COMANGO turut dikatakan memperjuangkan hak untuk bekerja, hak untuk hidup, dan hak untuk privasi dan memperjuangkan kebebasan bersuara dan berpersatuan di Malaysia (ibid).

Pelbagai pandangan dan diskusi telah diterbitkan di media akhbar pada waktu itu, terutamanya oleh media akhbar arus perdana sehingga ia dijadikan sebagai isu politik untuk kelangsungan parti-parti politik terutamanya dari pihak kerajaan (Hamayotsu, 2013; Hamayotsu, 2015). Malah, salah seorang pendukung COMANGO, Honey Tan Lay Ean turut menyatakan isu ini telah sengaja dimainkan di media oleh pihak berkepentingan tertentu tanpa sebarang usaha dialog diadakan antara pihak COMANGO dan orang awam (Earinie dan rakan-rakan, 2019).

Sesuatu yang perlu difahami adalah Industri akhbar di Malaysia adalah salah satu cabang institusi dominan yang popular di Malaysia yang secara tidak langsung memuat dan mengagihkan nilai-nilai dan pandangan-pandangan golongan-golongan dominan tertentu dalam masyarakat (Juliana dan Mahyudin, 2009). Malah media akhbar arus perdana di Malaysia sebelum Pilihan raya ke-14 pada tahun 2018 dikatakan telah dikuasai sebahagian besarnya oleh UMNO dan parti-parti komponen lain dalam Barisan Nasional (Wang, 2001; Zaharom \& Wang, 2004; Lansner, 2014). Industri media akhbar perlu dilihat sebagai suatu institusi yang sarat dengan ideologi-ideologi tertentu (Juliana dan Mahyudin, 2009) yang mana industri akhbar tidak beroperasi dalam kekosongan. Peranan industri akhbar yang beroperasi dalam dunia kapitalis bermotifkan keuntungan serta penyebaran wacana-wacana tertentu perlu diambil kira dalam usaha kita memahami kompleksiti hubungan akhbar dan ideologi dan pembentukan makna dalam masyarakat (ibid).

Oleh itu, artikel ini bertujuan untuk mengkaji mesej-mesej dan wacana yang disampaikan kepada khalayak oleh akhbar arus perdana di Malaysia iaitu Utusan Malaysia dan The Star, yang sebelum ini dimiliki oleh parti UMNO dan MCA di bawah Barisan Nasional mengenai isu tuntutan COMANGO ini. Wang (2015) menyatakan peranan yang dimainkan oleh media akhbar dalam mengekalkan hegemoni atau mengatasi konflik adalah sangat penting untuk dikaji memandangkan ia dapat memaparkan hubungan kekuasaan dan bagaimana hubungan kuasa ini mempengaruhi praktis-praktis budaya. Antara persoalan kajian adalah:

a. Berapakah frekuensi berita yang diterbitkan oleh akhbar Utusan Malaysia dan The Star mengenai isu ini? 
b. Apakah sumber berita yang digunakan oleh kedua-dua akhbar yang dikaji dalam melaporkan mengenai isu ini?

c. Apakah tema yang digunakan oleh kedua-dua akhbar dalam melaporkan mengenai isu ini?

d. Apakah kecenderungan pemberitaan oleh kedua-dua akhbar dalam melaporkan mengenai isu ini?

\section{Latar belakang kajian: Islamisasi di Malaysia}

Neo (2006) dan Jha (2009) menjelaskan bahawa negara Malaysia sebelum ini pada awal tahun 1970-an telah mengamalkan ajaran Islam yang sederhana dan hidup dalam harmoni dengan masyarakat bukan Islam yang lain. Namun, negara Malaysia mula merasakan impak daripada kebangkitan gerakan Islam yang berlaku di Iran, Afghanistan dan Sudan pada tahun 1970-an (Neo, 2006; Jha, 2009, Zaki Samsudin, 2010). Malah kebangkitan gerakan Islam ini semakin berkembang hasil pengaruh gerakan Islam di Timur Tengah seperti kumpulan Ikhwanul Muslimin dan berlakunya penyebaran dari penulisan-penulis pemikir-pemikir Islam terkenal seperti Hassan Al-Banna, SAyyid Qutb dan Sayyid Abul A'la Mawdudi (Zaki, 2010). Gerakan-gerakan ini turut mempengaruhi gerakan Islam di Malaysia yang mana organisasiorganisasi Islam di Malaysia seperti ABIM dan PKPIM telah disokong oleh golongan muda yang turut diketuai suatu ketika dahulu oleh Datuk Seri Anwar Ibrahim (ibid). Gerakan ini turut menjadi semakin berpengaruh ketika pentadbiran Tun Mahathir Mohamad, yang mana agama Islam menjadi semakin penting dan menonjol di sfera awam Malaysia (Neo, 2006:95).

Wacana mengenai Islam menjadi semakin menonjol apabila berlakunya pertembungan antara kerajaan Persekutuan yang diketuai oleh UMNO dalam gabungan Barisan Nasional dan parti pembangkang, iaitu Parti Islam Se-Malaysia (PAS) yang mana kedua-dua parti ini mengaku sebagai parti yang benar-benar ingin memperjuangkan Islam di Malaysia (Neo, 2006; Osman, 2013; Ahmad Fauzi, 2018). PAS adalah sebuah parti yang sangat kuat dalam kalangan rakyat Melayu Islam terutamanya di kawasan kampung malah menjadi salah sebuah parti yang paling lama memerintah di salah sebuah negeri di Malaysia iaitu Kelantan (ibid). Bagi memenangi sokongan masyarakat Melayu Islam dalam arena politik negara, parti UMNO telah mengambil beberapa pendekatan dan polisi kerajaan yang berbentuk Islamik untuk "melawan" versi Islam yang diperjuangkan oleh PAS (ibid). Malah polisi-polisi Islamik yang diperkenalkan ini lebih berbentuk politik hanya untuk mengekalkan sokongan golongan Melayu Islam dan cuba menunjukkan parti UMNO sebagai parti yang benar-benar memperjuangkan Islam dan Melayu di Malaysia (ibid). Oleh itu, proses Islamisasi ini dilihat sebagai usaha parti UMNO untuk mengekang pengaruh parti PAS dalam kalangan masyarakat Melayu Islam di Malaysia. Kesan daripada "pertarungan" antara parti PAS dan UMNO ini yang mana "lebih Islamik" menyebabkan pelbagai polemik dan polisi keagamaan diperkenalkan tanpa mengambil kira pandangan dan reaksi masyarakat bukan Islam di Malaysia (Neo, 2006; Zaki, 2010; Osman, 2013; Rashaad, 2016, Ahmad Fauzi, 2018).

Langkah-langkah ini membimbangkan kumpulan bukan Melayu / Islam di Malaysia kerana mereka risau perkara ini boleh mendatangkan kesan kepada masa hadapan mereka. Masyarakat bukan Islam juga merasakan komitmen pihak kerajaan untuk menerapkan dasar kepelbagaian budaya dan etnik sebagai sebahagian daripada Perlembagaan negara telah dikhianati oleh pihak kerajaan yang diterajui UMNO (Neo, 2006: 95; Abdull Rahman, Kamaruddin, Ahmad Sunawari Long, dan Faudzinaim, 2009; Rashaad, 2016). Fenomena Islamisasi ini juga cenderung menyebabkan penganut agama Kristian, Buddha, Hindu dan agama lain di Malaysia merasa terancam dan kabur mengenai masa hadapan agama dan budaya mereka (Abdull Rahman \& rakan-rakan, 2009). Islamisasi ini juga menyebabkan sentimen kebencian terhadap golongan Melayu Islam semakin meningkat dalam kalangan masyarakat bukan Islam di Malaysia (Rashaad, 2016).

\section{Kerangka teori: Hegemoni dan ideologi}

Salah satu konsep penting dalam menghuraikan mengenai penguasaan media oleh pihak pemerintah adalah konsep ideologi dan hegemoni yang sangat penting untuk difahami. Ideologi melihat bagaimana budaya distruktur supaya golongan berkuasa mendapat kawalan yang maksima dengan konflik yang 
minima (Gramsci, 1971; Lim Lai Hoon, 2012). Selalunya, ideologi digunakan oleh golongan berkuasa untuk menindas masyarakat subordinat dan mengubah cara fikiran mereka.

Ideologi mempersoalkan struktur sosial yang sedia ada dan menyanjung kedudukan kelas pemerintah. Ideologi menggambarkan hubungan sosial dan bagaimana golongan pemerintah mengekalkan status quo mereka (Gramsci, 1971). Ideologi membenarkan keadaan yang sedia ada dalam masyarakat melalui nilai hidup dan pandangan dunia yang dihasilkan oleh golongan dominan. Penyebaran luasideologi ini seolaholah memberi haluan kepada ahli masyarakat supaya mereka menerima order yang sedia ada dan juga menerima peranan mereka dalam masyarakat sebagai sesuatu yang semulajadi (Gramsci, 197; Lim Lai Hoon, 2012).

Dalam pada itu, konsep hegemoni atau dominasi ideologi menyatakan apabila sesebuah ideologi itu mendominasi, ia akan meyekat sebarang cara lain untuk menjelaskan mengenai realiti. Konsep hegemoni telah ditakrifkan oleh Gramsci (1971) sebagai satu sistem persekutuan kelas di mana satu "kelas hegemoni" memainkan peranan kepimpinan politik ke atas "kelas bawahan" dengan "memenangi hati golongan ini". Hegemooni adalah sejenis kawalan yang digunakan oleh kelas dominan melalui proses pimpinan moral dan intelektual ke atas golongan didominasi untuk menerima status mereka sebagai golongan dipimpin. Mengikut pandangan Gramsci, kelas dominan telah berjaya memujuk kelas lain dalam masyarakat untuk menerima nilai moral, politik dan juga budaya yang dibentuk menerusi media massa.

Dalam konteks ini, media massa dijadikan alat untuk menyebarkan ideologi dominan iaitu nilai-nilai kelas yang memiliki dan mengawal media (Gurevitch \& rakan-rakan, 1982:26). Media selalu mempromosi, memilih dan mengetengahkan aspek-aspek tertentu mengenai realiti dan sering memihak kepada suara-suara pihak pemerintah yang memiliki dan mengawal media tersebut (Bennet, 2005). Ringkasnya, kelas pemerintah memperoleh kuasa menerusi persetujuan daripada kelas bawahan dengan menggunakan ideologi dan bahan-bahan budaya (Ng, 2002).

\section{Metod Kajian}

Kajian ini menggunakan kaedah analisis kandungan kuantitatif sebagai kaedah utama kajian dan turut menggunakan analisis kandungan kualitatif dalam menentukan tema pemberitaan oleh kedua-dua akhbar. Dalam kajian ini, perhatian diberikan kepada frekuensi pemberitaan, jenis berita yang disiarkan, sumber berita yang digunakan, tema utama yang dipersembahkan dan kecenderungan berita dalam melaporkan mengenai isu COMANGO ini.

Kajian ini telah mengumpul sampel kedua-dua akhbar yang dikaji dari 1 Oktober, 2013 sehingga 1 Mac, 2014, yang mana dalam lingkungan waktu ini, isu ini telah dibincangkan secara meluas oleh kedua-dua akhbar. Isu ini telah dianggap tidak lagi menjadi isu yang hangat apabila pihak kerajaan pada ketika itu telah mengambil keputusan untuk mengharamkan pertubuhan COMANGO ini apabila didakwa tidak berdaftar dengan Jabatan Pendaftaran Pertubuhan Malaysia (ROS) (Farik Zolkepli, 2014).

Kajian ini akan menggunakan kaedah persampelan 'census sample' yang mengkaji kesemua unit dan terdapat sarjana yang menyatakan 'census sample' sangat berguna dalam mengkaji mengenai sesuatu peristiwa atau siri peristiwa (Riffe, Lacy \& Fico, 2005). Lebih besar sampel kajian, semakin kurang bias keputusan kajian yang akan didapati. Kesemua jenis artikel berita terbasuk berita langsung, artikel editorial, kolum, rencana dan surat pembaca dipilih untuk dikaji dalam kajian ini.

Dari sudut pemilihan sampel, akhbar Utusan Malaysia dan The Star dipilih kerana kedua-duanya adalah akhbar arus perdana yang mempunyai kaitan dengan pihak kerajaan sebelum ini iaitu Barisan Nasional (Wang, 2001; Zaharom Nain \& Wang, 2004). Utusan Malaysia adalah sebuah akhbar berbahasa Melayu yang mensasarkan pembacanya dalam kalangan masyarakat Melayu manakala akhbar The Star mensasarkan golongan pertengahan dan mampu berbahasa Inggeris. Menurut Laporan Audit Bureau of Circulations Malaysia dan Ac Nielsen pada tahun 2015, jumlah edaran purata harian akhbar Utusan Malaysia adalah sebanyak 503,592, menjadikan ia antara akhbar bahasa Melayu paling popular pada 
ketika itu. Manakala akhbar The Star mencatarkan jumlah edaran paling tinggi untuk akhbar berbahasa Inggeris dengan 546,553 cetakan (Circulation Figures - Paid Newspapers print edition Geographical Distribution - West \& East Malaysia, 2016).

Akhbar Utusan Malaysia sebelum Pilihan Raya ke-14 pada 2018 sering kali dikatakan mencetuskan ketegangan kaum dan agama dari sudut pelaporannya dan dikait rapat dengan pemilikan dari parti UMNO. UMNO turut dikatakan memiliki saham dalam Kumpulan Utusan, yang turut memiliki akhbar Kosmo! Dan beberapa akhbar mingguan lain (Lanser, 2014). Manakala akhbar The Star yang dimiliki oleh parti MCA, salah sebuah parti komponen dalam Barisan Nasional didapati turut mengamalkan pelaporan yang berhati-hati mengenai parti UMNO namun lebih bersifat neutral dalam pemberitaan mereka mengenai isu-isu yang melibatkan agama dan perkauman (Muhammad Raqib dan Adnan Hussein, 2014; Muhammad Raqib dan Adnan Hussein, 2018).

Oleh itu, adalah sesuatu yang menarik untuk dikaji bagaimana isu mengenai tuntutan COMANGO dilaporkan oleh kedua-dua akhbar arus perdana ini memandangkan kedua-dua akhbar ini sering kali dijadikan "alat" oleh pihak pemerintah dalam menyebarkan propaganda mereka (Halimahton \&rakanrakan, 2006; Aini Maznina \& Nerawi Sedu, 2015 dan Eichenauer, 2016).

\section{Hasil Kajian \& Perbincangan Kajian}

\section{Frekuensi berita}

Hasil kajian pengumpulan data dari tempoh 1 Oktober, 2013 sehingga 1 April, 2014 berjaya mengumpulkan sebanyak 164 artikel berita dari kedua-dua sampel akhbar yang dikaji. Dari 164 artikel berita tersebut, akhbar The Star menyiarkan 34 artikel berita (20.7 \%) manakala Utusan Malaysia sebanyak 130 artikel berita (57.8\%) (Jadual 1).

Jadual 1: Frekuensi berita

\begin{tabular}{ccc}
\hline Akhbar kajian & Jumlah & $(\%)$ \\
\hline The Star & 34 & 20.7 \\
Utusan Malaysia & 130 & 79.3 \\
Jumlah & 164 & 100.0 \\
\hline
\end{tabular}

Daripada hasil dapatan ini, dapat dilihat akhbar Utusan Malaysia lebih banyak menerbitkan artikel berita mengenai isu ini berbanding akhbar The Star dengan jumlah yang besar sekaligus menunjukkan akhbar Utusan Malaysia lebih banyak memberi keutamaan mengenai isu ini berbanding akhbar The Star.

\section{Jenis artikelberita}

Berdasarkan Jadual 2, dapatan kajian menunjukkan kedua-dua akhbar paling banyak menerbitkan artikel berita langsung dalam penerbitan mereka. Perkara ini mungkin disebabkan kebanyakan audiens menggemari berita jenis langsung kerana mudah untuk dibaca dan cepat untuk mendapatkan maklumat. Berita langsung juga banyak disiarkan oleh kedua-dua akhbar kerana ia lebih berbentuk pelaporan hasil dari soalan-soalan dari sidang media, kenyataan daripada pihak berkuasa, elit politik atau hanya melaporkan mengenai sesuatu isu yang berlaku tanpa memerlukan penyelidikan yang mendalam mengenai sesuatu isu.

Dapatan kajian ini juga bersesuaian dengan dapatan kajian-kajian yang telah dilakukan sebelum ini (Halimahton \&rakan-rakan, 2006; Yang \& Md Sidin, 2011; Yang \&Md Sidin, 2012; Yang \& Leong, 2017) yang mana kesemua kajian ini menunjukkan dalam melaporkan mengenai isu kontroversi melibatkan bangsa dan agama, akhbar-akhbar di Malaysia lebih cenderung untuk melaporkan mengenai isu tersebut dalam bentuk berita langsung dan tidak banyak menyiarkan artikel-artikel rencana yang berbentuk kritikal untuk mengelakkan sebarang konflik dalam kalangan masyarakat. 
Jadual 2: Jenis artikel berita

\begin{tabular}{llccc}
\hline & & \multicolumn{3}{c}{ Akhbar Kajian } \\
Jenis-jenis berita & & Utusan \\
Berita langsung & Kiraan & The Star & Malaysia & Jumlah \\
\multirow{3}{*}{ Kolum } & 32 & 99 & 131 \\
& \% antara akhbar kajian & $94.1 \%$ & $76.2 \%$ & $79.9 \%$ \\
Rencana & Kiraan & 0 & 11 & 11 \\
& \% antara akhbar kajian & $0.0 \%$ & $8.5 \%$ & $6.7 \%$ \\
Wawancara & Kiraan & 0 & 19 & 19 \\
& \% antara akhbar kajian & $0.0 \%$ & $14.6 \%$ & $11.6 \%$ \\
Jumlah & Kiraan & 2 & 1 & 3 \\
& \% antara akhbar kajian & $5.9 \%$ & $0.8 \%$ & $1.8 \%$ \\
& Kiraan & 34 & 130 & 164 \\
& \% antara akhbar kajian & $100.0 \%$ & $100.0 \%$ & $100.0 \%$ \\
\hline
\end{tabular}

\section{Sumberyang digunakan}

Berdasarkan Jadual 3, jenis sumber paling tinggi yang digunakan oleh akhbar The Star adalah dari kategori "pelbagai sumber". Pelbagai sumber di sini bermaksud akhbar The Star bukan hanya merujuk kepada satu pihak dalam pemberitaannya, namun merujuk kepada beberapa pihak dalam melaporkan mengenai isu ini.

Jadual 3: Sumber yang digunakan

\begin{tabular}{|c|c|c|c|c|}
\hline \multirow{3}{*}{\multicolumn{2}{|c|}{ Sumber berita }} & \multicolumn{2}{|c|}{ Akhbar kajian } & \multirow[b]{3}{*}{ Jumlah } \\
\hline & & \multirow{3}{*}{$\begin{array}{l}\text { The Star } \\
0\end{array}$} & \multirow{3}{*}{$\begin{array}{l}\text { Utusan } \\
\text { Malaysia }\end{array}$} & \\
\hline & & & & \\
\hline \multirow[t]{2}{*}{ Pemimpin Pakatan Rakyat } & Kiraan & & & 6 \\
\hline & $\%$ antara akhbar kajian & $0.0 \%$ & $4.6 \%$ & $3.7 \%$ \\
\hline \multirow[t]{2}{*}{ Pemimpin Barisan Nasional/ Menteri } & Kiraan & 8 & 24 & 32 \\
\hline & $\%$ antara akhbar kajian & $23.5 \%$ & $18.5 \%$ & $19.5 \%$ \\
\hline \multirow[t]{2}{*}{ Wakil dari NGO Islam } & Kiraan & 2 & 31 & 33 \\
\hline & $\%$ antara akhbar kajian & $5.9 \%$ & $23.8 \%$ & $20.1 \%$ \\
\hline \multirow{2}{*}{$\begin{array}{l}\text { Wakil dari NGO Islam yang } \\
\text { sederhana }\end{array}$} & Kiraan & 1 & 1 & 2 \\
\hline & $\%$ antara akhbar kajian & $2.9 \%$ & $0.8 \%$ & $1.2 \%$ \\
\hline \multirow[t]{2}{*}{ Agamawan Islam } & Kiraan & 0 & 3 & 3 \\
\hline & $\%$ antara akhbar kajian & $0.0 \%$ & $2.3 \%$ & $1.8 \%$ \\
\hline \multirow[t]{2}{*}{ Pendapat editor/ pengarang } & Kiraan & 0 & 14 & 14 \\
\hline & $\%$ antara akhbar kajian & $0.0 \%$ & $10.8 \%$ & $8.5 \%$ \\
\hline \multirow[t]{2}{*}{ Orang awam } & Kiraan & 0 & 1 & 1 \\
\hline & $\%$ antara akhbar kajian & $0.0 \%$ & $0.8 \%$ & $0.6 \%$ \\
\hline \multicolumn{2}{|c|}{ Wakil dari Persatuan Peguam-PeguamKiraan } & 0 & 3 & 3 \\
\hline Islam Malaysia & $\%$ antara akhbar kajian & $0.0 \%$ & $2.3 \%$ & $1.8 \%$ \\
\hline \multirow[t]{2}{*}{ Ahli PAS } & Kiraan & 1 & 0 & 1 \\
\hline & $\%$ antara akhbar kajian & $2.9 \%$ & $0.0 \%$ & $0.6 \%$ \\
\hline \multirow[t]{2}{*}{ Wakil MuslimUPRO } & Kiraan & 1 & 30 & 31 \\
\hline & $\%$ antara akhbar kajian & $2.9 \%$ & $23.1 \%$ & $18.9 \%$ \\
\hline Wakil dari kumpulan NGO & Kiraan & 3 & 3 & 6 \\
\hline COMANGO & $\%$ antara akhbar kajian & $8.8 \%$ & $2.3 \%$ & $3.7 \%$ \\
\hline \multirow[t]{2}{*}{ Pelbagai sumber } & Kiraan & 11 & 4 & 15 \\
\hline & $\%$ antara akhbar kajian & $32.4 \%$ & $3.1 \%$ & $9.1 \%$ \\
\hline Wakil dari badan hak asasi manusia & Kiraan & 4 & 0 & 4 \\
\hline
\end{tabular}


Malaysian Journal of Social Sciences and Humanities (MJSSH), Volume 6, Issue 1, (page 80 - 95), 2021

DOI: https://doi.org/10.47405/mjssh.v6i1.635

Bekas Perdana Menteri

Wakil dari NGO-NGO lain

Speaker Dewan Parlimen

Ahli akademik

Jumlah

\begin{tabular}{llll} 
\% antara akhbar kajian & $11.8 \%$ & $0.0 \%$ & $2.4 \%$ \\
Kiraan & 1 & 0 & 1 \\
$\%$ antara akhbar kajian & $2.9 \%$ & $0.0 \%$ & $0.6 \%$ \\
Kiraan & 1 & 3 & 4 \\
$\%$ antara akhbar kajian & $2.9 \%$ & $2.3 \%$ & $2.4 \%$ \\
Kiraan & 1 & 0 & 1 \\
\% antara akhbar kajian & $2.9 \%$ & $0.0 \%$ & $0.6 \%$ \\
Kiraan & 0 & 7 & 7 \\
\% antara akhbar kajian & $0.0 \%$ & $5.4 \%$ & $4.3 \%$ \\
Kiraan & 34 & 130 & 164 \\
$\%$ antara akhbar kajian & $100.0 \%$ & $100.0 \%$ & $100.0 \%$ \\
\hline
\end{tabular}

Berdasarkan analisis yang dijalankan oleh penyelidik, secara umumnya kesemua artikel yang menggunakan kategori "pelbagai sumber" oleh akhbar The Star tidak menunjukkan terdapatnya perdebatan antara dua pihak yang berlawanan pendapat dalam sesebuah artikel berita mengenai isu tuntutan COMANGO ini. Contohnya, sumber-sumber yang digunakan adalah seperti dari pihak COMANGO sendiri, Human Rights Commission of Malaysia (Suhakam), Human Rights Movement (Proham), Global Movement of Moderates, Sisters in Islam dan Centre of Independent Journalism yang rata-ratanya membincangkan mengenai keadaan dan senario hak asasi manusia di Malaysia yang dikatakan masih tidak mencapai pada tahap yang memuaskan. Artikel-artikel yang menggunakan kategori "pelbagai sumber" ini melaporkan antaranya mengenai kelemahan pihak kerajaan terdahulu dari Barisan Nasional dalam membentangkan senario sebenar hak asasi manusia di Malaysia di Geneva, tuntutan-tuntutan yang dilakukan oleh COMANGO dan MuslimUPRO di Geneva dan kaedah-kaedah yang boleh diambil untuk menambah baik keadaan hak asasi manusia di Malaysia.

Selain kategori pelbagai sumber, The Star juga banyak merujuk kepada kepimpinan Barisan Nasional khususnya dari UMNO, MCA dan menteri-menteri yang terlibat dalam isu tuntutan COMANGO ini. Contohnya, terdapat dalam sebuah artikel yang merujuk kepada pimpinan MCA yang mengkritik pihak kerajaan yang mengharamkan pertubuhan COMANGO dengan menyatakan tindakan tersebut sebagai cubaan untuk melenyapkan kebebasan bersuara. Memandangkan MCA adalah pemilik saham terbesar dalam The Star, maka bukanlah sesuatu yang menghairankan untuk akhbar tersebut merujuk kepada pimpinan MCA dalam mengeluarkan kenyataan mengenai isu ini.

Berdasarkan jadual di atas juga, dapat dilihat akhbar The Star memberi ruang untuk NGO-NGO lain yang merujuk kepada NGO selain agama Islam dalam memberikan pandangan mereka mengenai keadaan hak asasi manusia di Malaysia seperti Proham dan Suhakam. The Star juga dilihat memberi ruang kepada pihak COMANGO untuk menyatakan pendirian mereka mengenai isu tersebut. Tidak ketinggalan juga, berbanding akhbar Utusan Malaysia, The Star langsung tidak menggunakan pendapat editor atau pengarangnya dalam melaporkan mengenai isu ini sekaligus tidak dapat dilihat pandangan atau pendirian akhbar tersebut dengan jelas mengenai isu ini.

Bagi sampel akhbar Utusan Malaysia pula, akhbar tersebut paling tinggi menggunakan sumber berita dari kategori pemimpin Barisan Nasional, terutamanya menteri dari parti UMNO dan NGO Islam. Kebanyakan sumber dari pemimpin Barisan Nasional yang dirujuk adalah dari kalangan ahli UMNO yang begitu marah dan membantah mengenai tuntutan oleh COMANGO tersebut yang dikatakan menggugat kedudukan agama Islam di Malaysia. Bagi NGO Melayu Islam pula, kebanyakan artikel merujuk kepada Perkasa, Persatuan Peguam-Peguam Muslim Malaysia (PPMM), Ikatan Muslimin Malaysia (ISMA), Persatuan Pembela Islam (Pembela), Pertubuhan Muafakat Sejahtera Masyarakat Malaysia (Muafakat), Pengerusi Gabungan Pertubuhan-pertubuhan Islam Bukan Kerajaan (ACCIN) dan sebagainya yang juga turut membantah tuntutan oleh COMANGO tersebut.

Selain pemimpin UMNO dari Barisan Nasional dan NGO Melayu Islam, Utusan Malaysia juga banyak menggunakan sumber dari wakil MuslimPRO. Wakil dari MuslimUPRO banyak dirujuk dalam memberikan pandangan mereka dan pesanan-pesanan khas yang disampaikan oleh mereka dari Geneva yang meminta dan memohon pihak kerajaan dan rakyat Malaysia yang beragama Islam khususnya untuk menolak tuntutan yang dilakukan oleh pihak COMANGO ini. Muslim UPRO bertindak sebagai satu 
gabungan untuk kesemua NGO-NGO Islam yang lain untuk persiapan menghadapi tuntutan-tuntutan yang dikatakan mencabar Islam di Malaysia.

Selain itu juga, akhbar Utusan Malaysia banyak menggunakan sumber dari pendapat editor/pengarang yang membantah dan mengecam tuntutan yang dilakukan oleh COMANGO tersebut melalui artikel rencana pendapat dan kolum milik editor-editornya. Dapatan kajian juga menunjukkan sangat sedikit artikel beritanya yang merujuk kepada pihak COMANGO dalam melaporkan mengenai isu ini. Hanya tigaartikel sahaja yang diterbitkan merujuk kepada pihak COMANGO yang dijadikan sebagai bahan berita. Malah Utusan Malaysia menggunakan sumber-sumber dalam kalangan ahli akademik yang cenderung untuk membantah tuntutan-tuntutan yang dilakukan oleh pihak COMANGO.

Dapatan kajian ini selari dengan apa yang dinyatakan oleh kajian-kajian lepas (Muhammad Raqib \& Adnan Hussein, 2014; Aini \& Nerawi, 2015; Eichenauer, 2016, Yang \& Leong 2017; Muhammad Raqib \& Adnan Hussein, 2018) iaitu media arus perdana di Malaysia sering dikaitkan dengan sumber yang berpaksikan status quo dan menyebabkan kebergantungan media arus perdana kepada sumber dari parti pemerintah begitu tinggi. Dapatan kajian ini mengesahkan apa yang dinyatakan oleh sarjana-sarjana ekonomi politik (Murdock d\& Golding, 1973:205; Mosco, 1996; Golding \& Murdock, 2000) yang menyatakan bahawa hubungan kuasa yang membentuk pengeluaran, pengedaran serta penggunaan media akan memberi kesan kepada wacana dan representasi yang dipaparkan dalam sesebuah media itu.

\section{Kecenderungan berita}

Dapatan kajian dalam Jadual 4 mendapati akhbar Utusan Malaysia lebih banyak menyiarkan artikel yang tidak menyokong tuntutan yang dibuat oleh COMANGO tersebut. Malah tiada langsung berita yang menyokong tuntutan oleh COMANGO tersebut diterbitkan oleh Utusan Malaysia. Manakala akhbar The Star turut mengambil pendekatan yang sama apabila tiada langsung berita-berita yang diterbitkan menyokong atau memberi ruang kepada pihak COMANGO untuk memberikan penjelasan mereka kepada pihak media mengenai dakwaan yang dilemparkan kepada mereka yang kononnya mereka mempromosikan seks bebas dan menggugat kedudukan Islam di Malaysia.

Jadual 4: Kecenderungan berita

\begin{tabular}{|c|c|c|c|c|}
\hline \multirow[b]{2}{*}{ Kecenderungan berita } & & \multicolumn{2}{|c|}{ Akhbar Kajian } & \multirow[b]{2}{*}{ Jumlah } \\
\hline & & The Star & Utusan Malaysia & \\
\hline Menyokong & Kiraan & $\overline{0}$ & 0 & 10 \\
\hline & $\%$ antara akhbar kajian & 0 & $0.0 \%$ & $6.1 \%$ \\
\hline Tidak menyokong & Kiraan & 8 & 111 & 119 \\
\hline & $\%$ antara akhbar kajian & $23.5 \%$ & $85.4 \%$ & $72.6 \%$ \\
\hline Neutral & Kiraan & 16 & 19 & 35 \\
\hline & $\%$ antara akhbar kajian & $76.5 \%$ & $14.6 \%$ & $21.3 \%$ \\
\hline Jumlah & Kiraan & 34 & 130 & 164 \\
\hline & $\%$ antara akhbar kajian & $100.0 \%$ & $100.0 \%$ & $100.0 \%$ \\
\hline
\end{tabular}

Namun begitu, akhbar The Star lebih banyak menyiarkan artikel yang menentang pengharaman pertubuhan COMANGO oleh pihak kerajaan yang dikatakan tidak berdaftar dengan Jabatan Pendaftaran Pertubuhan Malaysia (ROS). Beberapa artikel yang diterbitkan dengan jelas mengkritik pihak kerajaan yang dikatakan telah menghalang pertubuhan tersebut dari kebebasan bersuara.

Artikel yang berbentuk 'kritikal' dalam kategori ini bermakna artikel-artikel yang diterbitkan tidak menyokong tuntutan yang dilakukan oleh COMANGO tersebut manakala 'neutral' bermakna artikel tersebut tidak menunjukkan kecenderungan sama ada menyokong atau tidak menyokong tuntutan COMANGO tersebut.

Bagi memberikan pemahaman yang lebih mendalam mengenai kecondongan arah berita ini, contoh kandungan berita yang menunjukkan arah berita yang negatif terhadap tuntutan oleh pihak COMANGO adalah seperti berikut: 


\begin{abstract}
"Tuntutan-tuntutan yang dibuat oleh Gabungan NGO-NGO Hak Asasi Manusia (COMANGO) kepada Majlis Hak Asasi Manusia Pertubuhan Bangsa-Bangsa Bersatu (PBB) dianggap tidak menghormati kedudukan Islam sebagai agama Persekutuan.
\end{abstract}

Ketua Delegasi Pertubuhan- pertubuhan Islam Dalam Proses Semakan Berkala Sejagat (MuslimUPro) ke Geneva, Switzerland, Azril Mohd. Amin berkata, tindakan COMANGO itu sengaja menimbulkan kekeliruan seolah- olah Malaysia adalah sebuah negara sekular yang meletakkan semua agama sama rata.

Menurut beliau, perbuatan itu bertujuan meletakkan apa sahaja dasar dan undangundang yang digubal kerajaan atau majlis-majlis agama Islam negeri di bawah seliaan serta pemerhatian Majlis HakAsasi Manusia PBB" (Hussaini Amran, 2013).

Contoh kandungan berita yang menunjukkan arah berita yang neutral terhadap tuntutan oleh pihak COMANGO pula adalah:

"Ketua Pembangkang, Datuk Seri Anwar Ibrahim dan Parti Keadilan Rakyat (PKR) diminta mengumumkan pendirian berhubung tuntutan-tuntutan yang dibuat oleh Gabungan NGO-NGO Hak Asasi Manusia (COMANGO) kepada Majlis Hak Asasi Manusia Pertubuhan Bangsa-Bangsa Bersatu (PBB) yang telah ditolak rakan sekutunya, Pas.

Presiden Pertubuhan Jaringan Cina Malaysia, Ng Lum Yoong juga mencadangkan agar nama COMANGO ditukar kepada Comangay sesuai dengan tuntutan yang mahu kerajaan mengiktiraf golongan lesbian, gay, biseksual dan transeksual (LGBT) di negara ini" (Termizi Che Anuar, 2013a).

Daripada dapatan kajian di atas, dapat dirumuskan bahawa akhbar Utusan Malaysia paling banyak menerbitkan artikel yang tidak bersetuju dan menentang tuntutan yang dilakukan oleh pihak COMANGO tersebut. Dapatan ini juga selari dengan dapatan kajian-kajian lepas (Muhammad Raqib \& Adnan Hussein, 2014; Yang \& Leong, 2017; Muhammad Raqib \& Adnan Hussein, 2018) yang mendapati akhbar Utusan paling banyak menyiarkan artikel-artikel yang tidak menyokong tindakan mana-mana pihak yang dilihat tidak menyebelahi Islam dan Melayu dalam isu-isu kontroversi melibatkan agama dan bangsa di Malaysia. Manakala akhbar The Star paling banyak menyiarkan artikel yang berbentuk neutral dalam penerbitannya yang turut selari dengan penemuan kajian-kajian lepas yang dilakukan yang melibatkan kontroversi kaum dan agama (Muhammad Raqib \& Adnan Hussein, 2014; Muhammad Raqib \&Adnan Hussein, 2018).

\title{
Tema utama artikel berita
}

Secara amnya, terdapat beberapa tema utama yang dibincangkan oleh akhbar Utusan Malaysia. Berdasarkan jadual di atas, Utusan paling banyak melaporkan mengenai tema berita yang mengkritik tuntutan COMANGO kerana bertentangan dengan ajaran Islam yang diamalkan di Malaysia. Perkataanperkataan seperti "tidak hormati Islam", "tuntutan batil", "mencabar kesyumulan Islam", "Comango patuk umat Islam", "ancam akidah umat Islam” dan "haram sokong COMANGO” menunjukkan kritikan yang diberikan penulis-penulis terhadap COMANGO dan kaitannya dengan Islam. Islam digambarkan sebagai tercabar dan COMANGO digambarkan sebagai sebuah persatuan yang tidak menghormati Islam di negara ini.

Selain itu, tema kedua yang paling banyak digunakan oleh akhbar Utusan Malaysia adalah menyeru pihak kerajaan supaya tidak tunduk dengan tuntutan COMANGO. Antara tajuk berita yang digunakan oleh akhbar Utusan Malaysia untuk menunjukkan seruan mereka terhadap kerajaan adalah "Kerajaan perlu tegas, jangan bertolak-ansur isu kesucian Islam", "Kerajaan jangan tunduk desakan asing iktiraf 
tuntutan COMANGO", "Ambil tindakan terhadap COMANGO", "Jangan terima tuntutan bercanggah Islam" dan "Jangan tunduk tekanan COMANGO".

Jadual 5: Tema utama artikel berita

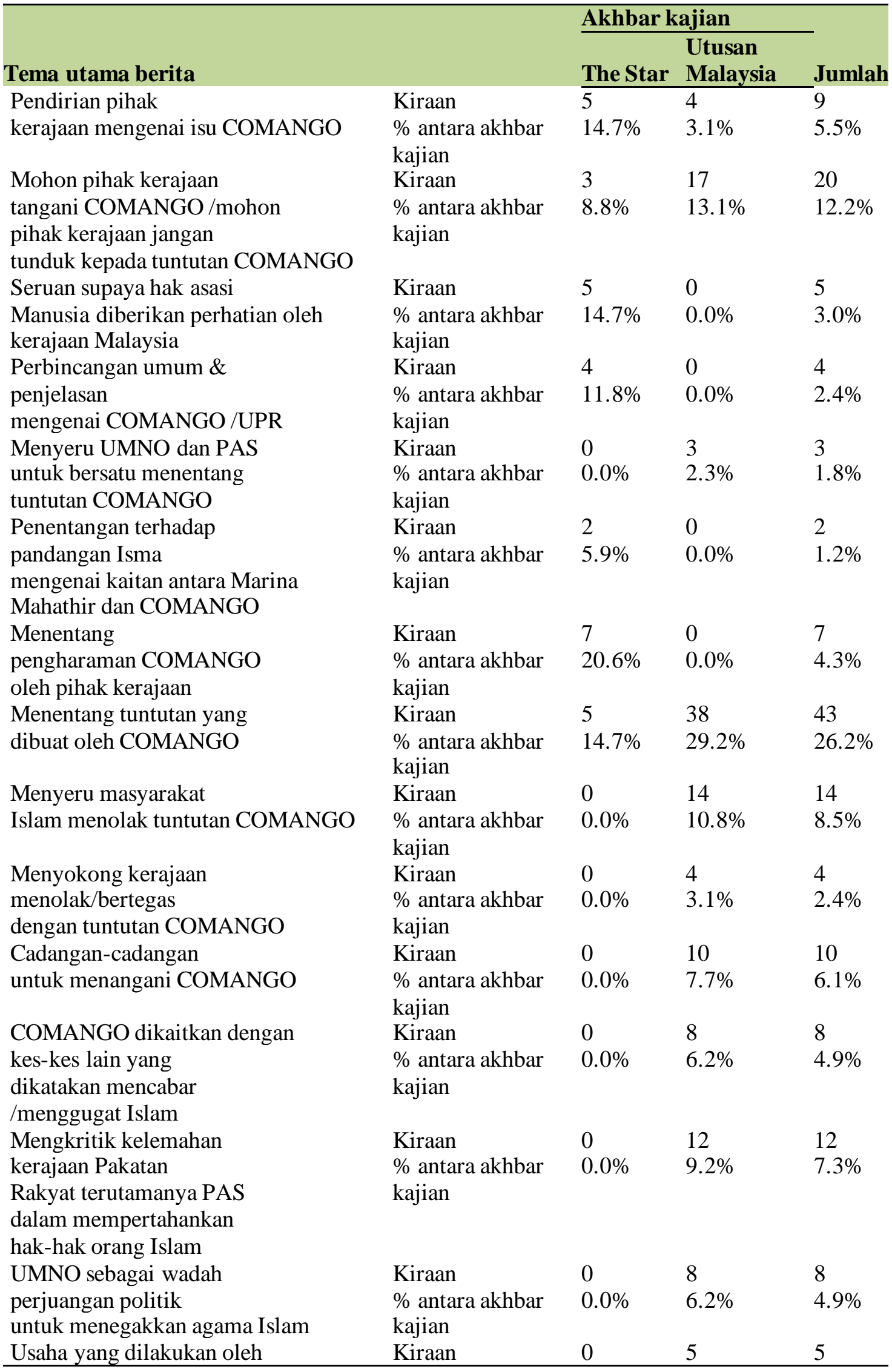


Malaysian Journal of Social Sciences and Humanities (MJSSH), Volume 6, Issue 1, (page 80 - 95), 2021

DOI: https://doi.org/10.47405/mjssh.v6i1.635

\begin{tabular}{lllll}
\hline NGO Islam untuk & $\begin{array}{l}\% \text { antara akhbar } \\
\text { menangani tuntutan COMANGO }\end{array}$ & $0.0 \%$ & $3.8 \%$ & $3.0 \%$ \\
Lain-lain (tema-tema kecil lain) & $\begin{array}{l}\text { kajian } \\
\text { Kiraan }\end{array}$ & 3 & 7 & 10 \\
& $\begin{array}{l}\% \text { antara akhbar } \\
\text { kajian }\end{array}$ & $8.8 \%$ & $5.4 \%$ & $6.1 \%$ \\
Jumlah & $\begin{array}{l}\text { Kiraan } \\
\% \text { antara akhbar } \\
\text { kajian }\end{array}$ & 34 & 130 & 164 \\
& & & $100.0 \%$ \\
\hline
\end{tabular}

Selain itu juga, tema bersatu padu antara umat Islam juga turut dibincangkan oleh akhbar Utusan Malaysia. Selain menyeru umat Islam untuk bersatu padu, parti UMNO dan PAS yang dilihat sering bertelagah pada ketika isu ini dibincangkan, sering kali diseru oleh penulis-penulis untuk mencari jalan penyelesaian kepada konflik yang berlaku antara mereka dan cuba mencari jalan untuk bersatu padu antara kedua-dua parti itu untuk menjamin masa hadapan umat Islam di Malaysia. Antara contoh tajuk berita yang digunakan adalah "Muzakarah UMNO-Pas: Isu COMANGO perlu jadi topik pertama", "Mencari kebersamaan nilai", "Desakan COMANGO petanda perpaduan lemah", "Berpecah punca COMANGO berani buat tuntutan", "Bersatulah, ketepikan ideologi politik", Kuasa penting, kesepakatan ideologi lebih utama" dan "Sampai bila mahu berpecah?".

Tidak ketinggalan juga, akhbar Utusan Malaysia turut membincangkan mengenai tema yang mengkritik kelemahan kerajaan Pakatan Rakyat terutamanya PAS dalam mempertahankan hak-hak orang Islam seperti yang dituntut oleh pihak COMANGO. Dalam mengkritik parti-parti Melayu Islam yang ada dalam Pakatan Rakyat, Utusan Malaysia turut membincangkan mengenai tema yang mengangkat parti UMNO sebagai parti yang benar-benar memperjuangkan Islam di Malaysia. Parti PAS dan PKR yang mempunyai ahli politik Melayu Islam digambarkan sebagai parti yang lemah dalam memperjuangkan Islam di Malaysia. Tajuk-tajuk seperti "Pembangkang sokong COMANGO?"; "Pas takut tempelak COMANGO", "Isu COMANGO: Diam tanda Anwar sokong?" dan "Pas masih dalam status-quo lama" digunakan seolah-olah untuk menunjukkan parti Pakatan Rakyat yang merupakan parti pembangkang pada ketika itu menyokong segala tuntutan COMANGO dan parti PAS terutamanya dilihat gagal untuk memperjuangkan Islam dengan sebaiknya dalam Pakatan Rakyat. Dalam pada itu, tajuk-tajuk berita yang digunakan untuk menunjukkan parti UMNO sebagai parti yang memperjuangkan Islam dalam konteks isu ini adalah seperti "UMNO sebagai benteng agama Islam", "Penegasan UMNO memartabatkan Islam" dan "Memperkasa Biro Agama UMNO".

Dalam pada itu, bagi akhbar The Star pula, akhbar tersebut paling banyak membincangkan mengenai penentangan terhadap pengharaman COMANGO oleh pihak kerajaan. Beberapa pihak telah dirujuk antaranya United Nations dan NGO-NGO seperti Suhakam, Proham, Sisters in Islam dan CIJ. Bagi menunjukkan penentangan ini, beberapa perkataan telah digunakan untuk menunjukkan kritikan terhadap tindakan pihak kerajaan tersebut. Antara perkataan yang digunakan adalah seperti "concerned", "abuse of power" dan "assault on freedom". Malah beberapa artikel yang diterbitkan turut memohon pihak kerajaan untuk menilai semula pengharaman tersebut dan pihak COMANGO juga telah mengeluarkan kenyataan untuk membawa kes pengharaman tersebut ke mahkamah.

Selain itu, akhbar The Star juga membincangkan mengenai tema penentangan terhadap tuntutan yang dibuat oleh pihak COMANGO di Geneva. Terdapat beberapa artikel yang diterbitkan merujuk kepada mantan Perdana Menteri pada ketika itu, Tun Dr Mahathir yang menyatakan pertubuhan COMANGO ini perlu disekat kerana setiap kebebasan yang diberi perlu ada hadnya. Selain itu, terdapat sebuah artikel yang membincangkan mengenai bagaimana parti UMNO cuba mendapatkan sokongan dari ahli PAS yang pada ketika itu bertindak sebagai parti pembangkang untuk menolak tuntutan COMANGO di Geneva. Selain itu juga, terdapat artikel yang melaporkan mengenai NGO Islam seperti JATI yang telah mengumumkan "perang" terhadap COMANGO yang dikatakan ingin menjadikan Malaysia sebagai sebuah negara liberal. Malah, terdapat juga sebuah artikel yang merujuk kepada salah seorang Ahli Majlis Tertinggi dari UMNO yang juga Ahli Parlimen Tanjung Karang, Datuk Seri Noh Omar yang mengutuk tuntutan yang dibuat oleh COMANGO tersebut. 
Tambahan lagi, akhbar The Star turut membincangkan mengenai tema yang menjelaskan mengenai pendirian kerajaan terhadap tuntutan-tuntutan yang dikemukan oleh COMANGO di persidangan di Geneva tersebut. Sebagai contoh, akhbar The Star dilihat merujuk kepada Perdana Menteri pada ketika itu, Datuk Seri Najib Tun Razak yang memberikan kenyataan "selamat" bahawa pihak kerajaan akan meneliti laporan tersebut terlebih dahulu sebelum membuat keputusan mengenai perkara ini. Selain itu, akhbar The Star turut merujuk kepada Timbalan Menteri Luar Negara pada ketika itu, Datuk Hamzah Zainuddin yang menyatakan bahawa pihak kerajaan hanya akan memperhalusi dan mengiktiraf perkaraperkara yang dituntut oleh pihak COMANGO jika ia mendatangkan kebaikan kepada negara. The Star dalam hal ini dilihat hanya memainkan peranannya sebagai "lidah kerajaan" dalam memberikan pandangan rasmi pihak kerajaan kepada masyarakat.

Walau bagaimanapun, akhbar The Star dilihat turut membincangkan mengenai tema yang menyeru supaya kerajaan Malaysia untuk memperjuangkan hak asasi manusia di Malaysia dengan lebih baik dan mengambil serius mengenai persidangan yang dijalankan di Geneva tersebut. Beberapa artikel yang diterbitkan menggunakan tajuk yang menggesa kerajaan untuk mengambil tindakan yang segera untuk memperbaiki mengenai keadaan hak asasi manusia di Malaysia. Antara tajuk yang digunakan adalah "Malaysia urged to ratify human rights treaties urgently" dan "Much to be done in Malaysia on human rights front". Malah terdapat juga artikel yang mengkritik pihak kerajaan dalam melaporkan mengenai kondisi hak asasi manusia di Malaysia di persidangan yang diadakan di Geneva tersebut. Antara tajuk yang digunakan adalah "NGOs disappointed with vague Govt statement at UPR" dan "Government's human rights report to UN slammed for being inaccurate".

Tidak ketinggalan juga, berbanding akhbar Utusan Malaysia, The Star turut membincangkan mengenai penafian Marina Mahathir dalam pertubuhan COMANGO. The Star dilihat memberikan peluang kepada anak kepada mantan Perdana Menteri Malaysia, Marina Mahathir yang juga aktivis hak asasi manusia untuk memberikan pandangan beliau mengenai dakwaan oleh NGO Melayu Islam, ISMA yang mengaitkan beliau sebagai salah seorang dalang yang menyokong tuntutan COMANGO tersebut yang dikatakan menggugat kedudukan Islam di Malaysia. The Star dilihat memberikan ruang dan peluang untuk Marina menyatakan pendiriannya mengenai isu COMANGO ini malah beliau turut memberikan amaran kepada ISMA untuk berhenti membuat tuduhan liar dan beliau turut menfailkan kes tuduhan liar tersebut ke mahkamah.

Oleh itu, dapatan kajian ini adalah selari dengan dapatan kajian Nur Kareelawati (2010), Muhammad Raqib dan Adnan Hussein (2014) dan Muhammad Raqib dan Adnan Hussein (2018) yang menyatakan akhbar Utusan Malaysia cenderung untuk memainkan isu perlunya bangsa-bangsa lain untuk menghormati dan patuh kepada kontrak sosial dan mempertahankan hak orang Melayu seperti yang termaktub dalam Perlembagaan negara. Dapatan kajian ini juga mengesahkan pendapat Ahmad Murad (2005) yang menyatakan akhbar berbahasa Melayu di Malaysia tidak akan lari dari mengaitkan Islam dan Melayu seperti yang termaktub dalam Perlembagaan negara dalam pelaporannya dan mengang gap agama Islam itu lebih "tinggi" berbanding agama lain di Malaysia. Perkara ini menunjukkan bahawa pihak pemerintah berusaha untuk menjalinkan nilai-nilai dan idea-idea Islam sebagai ideologi yang dominan kerana Islam dianggap sebagai pemangkin untuk memperkuat kekuasaan pihak pemerintah terhadap negara (Wan Norshira, 2019). Kedudukan hegemoni orang Melayu Islam juga dicipta oleh pihak pemerintah untuk memastikan ketuanan budaya dan politik orang Melayu melebihi etnik lain (ibid).

Dapatan ini juga selari dengan kajian-kajian lepas (Muhammad Raqib \& Adnan Hussein, 2014 dan Muhammad Raqib \& Adnan Hussein, 2018) yang menyatakan bahawa akhbar The Star dilihat lebih banyak membincangkan tema-tema yang lebih bersifat sederhana dan berhati-hati dalam mengkritik pihak-pihak yang terlibat dalam sesebuah isu kontroversi yang melibatkan agama dan kaum. Dalam kajian ini, akhbar The Star dilihat tidak menyentuh langsung mengenai kewajaran tuntutan-tuntutan yang dibuat oleh COMANGO, namun akhbar tersebut dilihat membincangkan isu hak asasi manusia di Malaysia ini dalam konteks yang lebih besar. The Star dilihat cuba untuk tidak memainkan sentimen agama dan perkauman dalam membincangkan mengenai isu tuntutan COMANGO ini. The Star juga dilihat berhati-hati dalam mengkritik kerajaan dengan tidak mengkritik secara terang-terangan pihak kerajaan dalam membincangkan mengenai laporan hak asasi manusia di Geneva tersebut. Akhbar The 
Star turut dilihat memberikan peluang dan ruang kepada mereka dari pihak COMANGO terutamanya dan mereka yang bersimpati dengan pertubuhan tersebut untuk menyatakan pendirian mereka selepas pertubuhan tersebut diharamkan oleh pihak kerajaan.

\section{Kesimpulan}

Secara kesimpulannya, akhbar Utusan Malaysia dan The Star melalui artikel-artikel yang dikaji dilihat cuba untuk terus menyokong ideologi dominan dan mengesahkan keadaan order sosial yang sedia ada walaupun terdapat beberapa artikel yang diterbitkan oleh akhbar The Star dilihat cuba untuk mengkritik tindakan pihak kerajaan yang mengharamkan pertubuhan COMANGO tersebut.

Dalam konteks ini, jelas sekali ideologi yang beroperasi pada tahap superstruktur, yang melibatkan penggunaan sistem media dan praktis budaya telah digunakan oleh pihak pemerintah untuk menyokong nilai-nilai elit pemerintah sekaligus mengekalkan status quo golongan ini. Seperti yang dinyatakan Juliana dan Mahyudin (2009), wacana-wacana yang dibentuk oleh sistem sosial yang sedia ada, sebenarnya mengawal dan menyekat pembentukan makna yang pelbagai, yang bersifat alternatif/kritikal sebaliknya mempromosikan pembentukan makna yang seragam, bersifat arus perdana seperti yang diinginkan oleh golongan dominan dalam sesebuah masyarakat.

Kajian ini juga menunjukkan bagaimana isu melibatkan agama Islam ini digunakan sebagai alat politik untuk mengekalkan kuasa yang sedia ada dan perkara ini dapat dilihat apabila begitu banyak artikel yang diterbitkan merujuk kepada sumber-sumber dari pemimpin UMNO. Malah tema-tema yang mengkritik parti pembangkang dan mengangkat parti UMNO turut digunakan oleh akhbar Utusan Malaysia sekaligus menunjukkan bagaimana isu ini turut dijadikan sebagai alat politik untuk manfaat parti UMNO. Perkara ini menunjukkan bagaimana hegemoni boleh dibentuk secara halus dengan menunjukkan parti UMNO sebagai parti yang benar-benar menjaga dan memelihara agama Islam di negara ini.

Dapatan kajian ini juga selari dengan apa yang dinyatakan oleh Gramsci (1971) iaitu bagi memastikan hegemoni itu terus berlaku secara berterusan, penguasaan minda yang dilakukan terhadap golongan bawahan adalah lebih penting. Perkara ini dapat dilihat apabila orang Melayu sering kali diingatkan mengenai sumbangan parti UMNO kepada masyarakat Melayu. Muhammad Nadzri Mohamed Noor dan Ghazali Mayudin (2008) menyatakan kedudukan elit UMNO yang tinggi dalam struktur sosial dan politik Melayu menyediakan ruang kepada pemimpin UMNO khasnya pemimpin tertingginya untuk menjadi hegemonik, iaitu berupaya menguasai sistem kemasyarakatan dengan dominasi ruang superstruktur dengan menggunakan media yang dikawalnya. Akhbar The Star pula yang mensasarkan pembacanya dalam golongan pertengahan dan pelbagai bangsa, dilihat gagal untuk melaporkan beritaberita yang kritikal terhadap isu yang berlaku malah turut menjadi "lidah" kepada pihak kerajaan dalam memberikan justifikasi tindakan yang diambil oleh pihak kerajaan dalam membincangkan mengenai isu tuntutan-tuntutan COMANGO ini.

\section{Rujukan}

Abdul Aziz, B. (2001). Perlembagaan Malaysia: asas-asas dan masalah. Kuala Lumpur: Dewan Bahasa dan Pustaka.

Abdul Qayyum, J. (2014). Why has Comango been banned? Poskod.my. https://poskod.my/cheatsheets/why-has-comango-been-banned/

Abdull Rahman, M., Kamaruddin, H. S., Ahmad, S. L. \& Faudzinaim, B. (2009), Penerimaan Bukan Islam Terhadap Proses Islamisasi Di Malaysia, Jurnal Hadhari. 2. 33-51.

Ahmad Fauzi, A. H. (2018). Islamisme dan Bahananya: Cabaran Besar Politik Malaysia Abad ke-21, Pulau Pinang: Penerbit Universiti Sains Malaysia.

Aini Maznina, A. M. \& Nerawi, S. (2015). Framing Islam-related issues during GE13: An analysis of Malaysian mainstream newspapers, Intellectual Discourse, 23 (1), 29-52. 
Bimbang tuntutan Comango (2013, 17th November). Utusan Malaysia.

Carmen, N. (2012). Melapor tentang 'Kaum' dan Etnisiti: Buku Panduan untuk Wartawan Malaysia. Selangor: Centre For Independent Journalism.

Circulation Figures - Paid Newspapers print edition Geographical Distribution - West \& East Malaysia (2016). Audit Bureau Circulations Malaysia. http://abcm.org.my/wp-content/reports/2016/abccirculation-figures-jan-16-to-june-16-newspapers-west-and-east-malaysia-distribution.pdf

Comango: Our UN report does not undermine Islam (2013, 17th October). Malaysiakini. https://www.malaysiakini.com/

Comango: We are not for rights against Islam (2014, 9th January). Malaysiakini. https://www.malaysiakini.com/

Earnie, E. H., Kamarudin S. \& Nur Farhana, A. R. (2019) Isu-isu pluralisme agama dalam Tuntutan Comango: Satu Analisis terhadap Laporan 2013 dan 2018. International Journal of Islamic Thought ( IJIT), 15 . pp. 35-43.

Eichenauer, E. (2016). Language, Mass Media, And Democracy: The Debate Over "Kalimah Allah" In The Malaysian Print And Online Media, Kajian Malaysia, Vol. 34 (1), 1-33.

Farik Z. (2014, 9 Januari). Home Ministry deems Comango illegal. The Star Online. https://www.thestar.com.my/news/nation/2014/01/09/home-ministry-deems-comango-illegalonly-15-organisations-registered-with-ros/

Golding, P. \& Murdock, G. (2000). Culture, Communications and Political Economy, dalam Curran, J. dan Gurevitch, M., Mass Media and Society. Third Edition. London: Arnold.

Gramsci, A. (1971). Selections from the prison notebooks. (E. A. Nowell-Smith, Ed.). New York: International Publishers.

Gurevitch, M., Bennett, T., Curran, J. \& Woollacott, J. (Ed.) (1982). Culture, Society and the Media. London: Methuen.

Halimahton S., Hua N.T., \& Raman, V. (2006). Covering race and religion: the Moorthy and Nyonya Tahir cases in four Malaysian Newspapers. Kajian Malaysia. Vol. XXIV (No.1 \& 2), 185-201.

Hamayotsu, K. (2013). Towards a More Democratic Regime and Society? The Politics of Faith and Ethnicity in a Transitional Multi-Ethnic Malaysia, Journal of Current Southeast Asian Affairs, 32 (2), 61-88.

Hamayotsu, K. (2015). Democracy and Religious Pluralism in Southeast Asia: Indonesia and Malaysia Compared, Working Paper. Key Issues in Religion and World Affairs. Henry Luce Foundation. 115.

Hussaini, A. (2013, 23rd October). Comango tak hormati Islam. Utusan Malaysia.

Jha, P.K. (2009). Religious Assertion in Malaysia: Constrained or Conflagrated? Strategic Analysis, 33:6, 890-902.

Juliana. A. W. \& Mahyuddin. A. (2009). Filem Box Office dan Ideologi: Satu Kajian Terhadap FilemFilem Terpilih di Malaysia, Wacana Seni. Vol.8. 43-68.

Lansner, T. R. (2014). Monopolizing the nation: Soft censorship in Malaysia. Paris: WANIFRA.

Lim, L. H. (2012). Akhbar, Sensasionalisme dan Kepanikan Moral: Satu Kajian Kes Pemberitaan Rogol-Bunuh dalam Akhbar Terpilih, Tesis PhD. Universiti Sains Malaysia.

Mohd Farid, M. S. (2012). Maaf, Tuhan Kita Tidak Sama, Mengulas Interaksi Agama di Malaysia. Kedah: Bitara Media.

Mosco, V (1996). The Political Economy of Communication: Rethinking and Renewal, SAGE Publications, London.

Muhammad Nadzri, M. N. \& Ghazali, M. (2008). Hegemoni Dan Kontra Hegemoni: Memahami Perubahan Pilihan Raya Umum Ke-12. Jebat, 35, 33-48.

Muhammad Raqib, M.S. \& Adnan, H. (2014). A Quantitative Content Analysis of Utusan Malaysia and The Star's Reporting on A Controversial Thanksgiving Dinner in Damansara Utama Methodist Churh, Malaysian Journal of Media Studies, 16 (2), 45-61.

Muhammad Raqib, M.S. \& Adnan, H. (2018). Gerakan Kristianisasi \& Peranan Media Di Malaysia: Satu Kajian Kes Terhadap Pelaporan Akhbar Utusan Malaysia Dan The Star, AL-ABQARI: Joumal of Islamic Social Sciences and Humanities, Vol 15 (2), 137-154.

Murdock, G.\& Golding, P. (1973). For a political economy of mass communications dalam Miliband, R. \& Saville, J. The socialist register 1973. London: Merlin Press. 
Neo, J. L. C. (2006). Malay nationalism, Islamic supremacy and the constitutional bargain in the multiethnic composition of Malaysia. International Journal on Minority and Group Rights, 13 (1). 95118.

Ng, M. L. (2002). Pemamparan Akhbar Berlainan Bahasa Di Malaysia Tentang Kejadian Demonstrasi Gerakan Reformasi Malaysia 1998 : Kajian Kes Terhadap Utusan Malaysia Sin Chew Jit Poh, Tesis Sarjana. Universiti Sains Malaysia.

Nur Kareelawati Abd. Karim. (2010). Reporting on Apostasy: Are Malaysian Newspapers at the Crossroads? dalam Maznah Buyong, Nur Kareelawati Abd Karim, Sofia Hayati Yusoff dan Suria Hani A Rahman, Portrayal Of Islam In The Media, (pp 209 - 226). Nilai: MNR Global Resources $\&$ Faculty of Leadership and Management. USIM.

Osman, S. (2013, 2 Ogos). Issues of religion and race a challenge for Malaysia, The Jakarta Post, http://www.thejakartapost.com/

Rashaad, A. (2016, 19 April). Minorities push against the state's race policies and politics: The threat to UMNO posed by Malaysia's rising Islamophobia, Today Online. https://www.todayonline.com/

Ridauddin, D. (2020, 11 Januari). Cara menangani isu perkauman. Sinar Harian. https://www.sinarharian.com.my

Riffe, D., Lacy, S., \& Fico, F. (2005). Analysing Media Messages: Using Quantitative Content Analysis in Research. New Jersey: Lawrence Erlbaum Associates.

Termizi, C. A. (2013a, 26th November). Anwar perlu umum pendirian. Utusan Malaysia.

Termizi, C. A. (2013b, 27th November). Rafizi diminta nyata pendirian. Utusan Malaysia.

Walters, A.S. (2007) Issues in Christian-Muslim Relations: A Malaysian Christian Perspective, Islam and Christian-Muslim Relations. 18 (1). 67-83.

Wan Norshira, W. M. G. (2019). Islam as The State Ideology: Exploring from Gramsci's Notion of Power, Culture and Ideology. Jurnal Komunikasi, Vol 35 (1), 338-352.

Wang, L. K. (2001). Media and Democracy in Malaysia. Journal of The European Institute for Communication and Culture (Jovnost). Vol. 8 (2). 67-88.

Wang, L. K. (2015), Komunikasi dan Budaya: Penyelidikan Komunikasi dan Teori Kritikal dalam Azman Azwan Azmawati, Mahyuddin Ahmad, Mustafa Kamal Anuar, Wang Lay Kim. Antologi Esei Komunikasi: Teori, Isu dan Amalan (3-18). Pulau Pinang: Penerbit Universiti Sains Malaysia.

Yang, L. F. \& Leong. W. K. (2017). Framing the Cow-Head Protest: A Comparative Analysis of The Star and Malaysiakini, SEARCH: The Journal of the South East Asia Research Centre for Communications and Humanities, Vol. 9 (1).71-96.

Yang, L.F. \& Md Sidin, A. I. (2011). Framing Religious Dispute: A Comparative Analysis of the Lina Joy Controversy by Malaysian Newspapers, The Journal of the South East Asia Research Centre for Communication and Humanities, Vol. 3 (2), 21-38.

Yang, L.F. \& Md Sidin, A. I. (2012). Framing Interethnic Conflict in Malaysia: A Comparative Analysis of Newspaper Coverage on the Hindu Rights Action Force (Hindraf). International Journal of Communication. 6. 166-189.

Zaharom, N. \& Wang, L. K. (2004). “Ownership, control and the Malaysian media”, in Thomas P. N. $\&$ Z. Nain, ed., Who owns the media: Global trends and local resistances (pp. 249-267). Penang, Malaysia: Southbound Sdn. Bhd.

Zaki Samsudin (2010, 25 Febuari). Islamisasi dan dasar penerapan nilai-nilai Islam. The Centre for Policy Initiatives. http://www.cpiasia.net/v3/index.php/230-Columnists/zaki-samsudin/1869islamisasi-dan-dasar-penerapan-nilai-nilai-islam- 